\title{
The Economics of Targeting and Sustaining a Niche Market: A Case Study of Green Pod Chickpea Marketing in Ethiopia
}

\author{
Yidnekachew Wondimu Zewde* \\ Socioeconomic Researcher, International Crops Research Institute for the Semi-Arid Tropics (ICRISAT) \\ P.o.Box 5689, Addis Ababa, Ethiopia \\ Asnake Fikre Wodemedhin \\ Regional Chickpea Breeder and Seed System Specialist, International Crops Research Institute for the Semi-Arid \\ Tropics (ICRISAT) \\ P.o.Box 5689, Addis Ababa, Ethiopia
}

\begin{abstract}
Ethiopia is a leading producer of chickpea in Sub-Saharan Africa and the crop plays substantial role in household food and nutrition security, soil fertility restoration and national export earnings. Recent market studies show that farmers often sell chickpea in grain form and it reaches the final consumer through complex and long supply channels involving various market actors. However, Green Pod Chickpea (GPCP) marketing is a recently evolving phenomenon as a niche market, and there has been a considerable boost in its supply over the past five years. The objective of this paper is to critically examine the main driving forces behind GPCP marketing and assess whether it is a viable and sustainable option for smallholder farmers. Despite the relevance of multilayer evidences, the research and development efforts to understand, evaluate and support GPCP marketing scheme are very much limited - the issue has not received the attention it deserves. Farmers are still relying on old varieties with very minimal extension support and the degree to which the niche market would be able to absorb the growing number of aspiring GPCP market participants is still unclear. In nutshell, there is limited information and knowledge about the size and characteristics of GPCP market. To the best of our understanding, this study is the first of its kind to critically examine the viability of GPCP marketing scheme, and we hope that the findings could help bridge the knowledge gap, provide policy inputs and serve as reference for further studies in the area. To answer the research questions, we have collected data from chickpea producers, extension workers and market actors, and the data has been analyzed using descriptive and econometric methods. The findings clearly show that GPCP marketing is variety-specific: the market strongly favors the localized black and improved Marye varieties mainly due to their taste. To make GPCP buying decision, market actors such as consumer and vendors consider certain crop parameters and attributes including, pod color, pod size, freshness, neatness, pods per plant, variety (Desi or Kabuli) etc. As the multiple regression results show, proximity to market, gender, livelihood status, family size, harvesting and post-harvesting costs, grain and GPCP price gap, and access to finance are the main factors affecting the amount of GPCP traded. Some farmers sell GPCP out of necessity motivated by cash deficit, whereas others are highly market-oriented and put effort to exploit the niche market led by profit maximization. The structure and functioning of GPCP market is quite different from that of grain market: it is less complex and involves few intermediaries with short supply chain. To widen market base, availing more GPCP products options and value addition efforts (cleaning, peeling, cooking, roasting, packaging, and labeling) could be crucial entry points. Besides, the research and extension system should address the concerns of GPCP producers and engage them during variety release, training provision and capacity building sessions. To shade more light on the scalability and future prospect of such marketing scheme, further studies pertinent to its structure and functioning are vital. At policy level, mainstreaming it into the food and nutrition product stream could have paramount importance. Keywords: Marketing Schemes, Green Pod Chickpea, Niche Market, Value Chain Actors, Viability, Scalability DOI: $10.7176 / \mathrm{JESD} / 10-15-06$
\end{abstract}

Publication date: August $31^{\text {st }} 2019$

\section{Introduction}

The deeply rooted tradition of peeling and eating legume crops such as Chickpea, Fababean and Field pea while they are still green is an admired ritual of most Ethiopians. Such practice of consuming fresh legumes is locally known as 'Eshet'. Despite the consumption practice at household level, market-oriented production and large-scale marketing of fresh or green legumes is a recently evolving phenomenon. Over the past five years, it has become a common practice to see young men and women selling freshly uprooted and picked Green Pod Chickpea (GPCP) (locally called 'Shimbra Eshet') along the streets of Addis Ababa, capital of Ethiopia and other regional cities. During the period from October to December, Addis Ababa enjoys GPCP freshly picked in their infancy, while they are still green, and coated in fury pale green pod (Genene 2013). At this time of the year, GPCP mainly comes from bordering districts and sold in the streets of Addis Ababa, a rapidly expanding capital city hosting about five million inhabitants. GPCP is a maturing seed filled green pod and it is often consumed as easily crunched as raw 
fresh or served with salads by roasting or cooking it with water. Among different chickpea varieties, many consumers pointed out that the old black localized variety has a sweet test with less salty flavor. In many parts of Ethiopia, even if people do not have chickpea planted in their own fields, there is a tendency of picking and consuming GPCP from passersby's fields for immediate consumption. Although it violates private property right, the owners are often benevolent and tolerate to this behavior. Recently, some people tend to abuse this old tradition of reciprocal benevolence for commercial intent and this has negatively affected producers. Thus, in some areas, chickpea producers have drafted community rules and bylaws to punish those who violate the tradition and norms of the society.

The existing evidences show that GPCP marketing scheme offers option for farmers to realize untapped potentials, despite the risks, challenges and limitations associated with it (Dadi et al. 2005). To address these issues, GPCP marketing scheme has got very limited research and development attention, and it has not been well supported by appropriate technology options. Empirical evidences with a view to study the viability of GPCP marketing and examine the underlying impact of such marketing scheme on livelihood are still utterly missing, but highly needed. As many consumers and nutritionists strongly argue, GPCP is organic, fresh, healthy and affordable. In the study areas, the period from September to December is often identified as food deficit period: most crops are either in flowering stage or in a very early stage of development. The selling of GPCP fills the cash deficit of many resource poor households because it helps them bridge the gap and eases the burden of transition towards harvesting. On the other hand, producers and agronomists complain that GPCP marketing has its own disadvantages: to mention a few, it (i) has limited market options, (ii) is highly risky because of perishability, (iii) disrupts soil Nitrogen fixing process by early uprooting of chickpea, and (iv) leads to fragmentation of efforts in product marketing.

A niche is a focused, targetable part of the market and it is small but profitable segment of a market suitable for focused attention by a marketer (Hellin and Higman 2002; Thilmany 2012). GPCP selling farmers are providing a specific variety of chickpea (mainly the black localized variety), which is not being supplied by mainstream grain chickpea suppliers. It is a niche market because they have unique knowledge and expertise to meet the specific demand of GPCP buyers in Addis Ababa. The niche is defined based on certain needs and preferences of the urban consumers. To this end, the study focuses on (1) psychographic factors that let GPCP consumers memorize their rural identity and rural values, and (2) health consciousness aspects indicate the fat that GPCP is organic, fresh and nutritious. With proper targeting and segmentation, marketing to a niche is much easier than appealing to a broad market, since a niche has much more in common in terms of needs, wants, or preferences.

The main objective of this paper is to critically examine the main driving forces behind GPCP marketing and assess whether it is a viable option for smallholder chickpea producers. Over the past 3 to 5 years, evidences show that there has been dramatic increase in marketing of GPCP. In fact, this trend raises important research questions:

1. Why do farmers prefer to sell GPCP instead of using the conventional marketing approach of grain marketing? In other words, what are the main driving forces for chickpea producers to choose such marketing scheme?

2. What are the socio-economic significances and implications of marketing such product?

3. What are the incentives, merits, and demerits of GPCP marketing scheme?

4. Who are the main value chain actors in GPCP marketing and how does the market function (i.e., overall structure of GPCP market)?

5. What are the key parameters or desirable product attributes a GPCP selling farmer need to consider while selling chickpea in green or fresh form?

With a view to answer these questions, we have generated multilayer evidences from chickpea producers, extension workers, and market actors (e.g., GPCP vendors, grain sellers, processors, and brokers). A survey data has been collected from 72 GPCP selling farmers from six kebeles ${ }^{1}$ of Akaki district of Oromia regional state. We have also carried out Focus Group Discussions with communities and conducted interviews with key informants at kebele and district level. The paper is organized as follows: section-I gives a brief overview of chickpea production and marketing in Ethiopia. Section-II discusses the research processes and methods of data collection and analyses. Section-III is mainly devoted to data analyses and discussions. Section-IV presents the summary of findings and concluding remarks coupled with different policy prescriptions and recommendations related to alternative chickpea marketing schemes.

\subsection{A Glimpse on Chickpea Production and Marketing in Ethiopia}

To put the issue into context, it is vital to give a brief overview of how important the chickpea sub-sector is to the household and national economy. As a legume crop, chickpea offers natural soil maintenance benefits using Nitrogen-fixation, which improves yields of cereals through crop rotation and reduces the need for fertilizer in the next cropping season. Gross profit analyses also show that production of chickpea ensures decent income for farmers, without even taking into account the additional benefits of nitrogen fixation or double cropping possibilities (IFPRI 2010). According to our assessment, farmers' main reasons for producing chickpea include its 
market value (63\%) and role of improving productivity of land for cereals $(28 \%)$. Nationally, on average, a farmer plants chickpea on 0.24 hectare of land. However, chickpea is still treated as precursor crop and receive less investment and policy attention unlike cereal crops often referred as principal and food security crops (Chilot et al. 2010).

A wider adoption of chickpea technologies has received attention due to price incentives and its role in human nutrition (as a good source of protein). During the past 10 years, the chickpea sub-sector has shown a steady increase in productivity and total volume of production mainly due to wider adoption of improved variety seed and agronomic packages (Asfaw et al. 2010a; Asfaw et al. 2010b; Asfaw et al. 2012; Atnaf et al. 2015; Aw-Hassan et al. 2015; Chichaybelu et al. 2017; Demissie 2011; Gowda et al. 2014; Rao et al. 2012; Tefera 2014; Verkaart et al. 2017; Verkaart et al. 2018; Yadav et al. 2007; Zegeye et al. 2016). As indicated in Figure-1, during the ten-year period of 2006 to 2016, average chickpea yield increased by $90 \%$ (1 to 1.9 tons per hectare). In fact, in potential areas of Adaa and Akaki districts, with the appropriate application of technologies the chickpea yield reached as high as 3.5 tons per hectare (Fikre 2014). This gain in productivity led to increase in smallholder income by 40 to $70 \%$ per hectare and also improved nutrition security through meeting domestic protein demand (Rashid et al. 2010).

Ethiopia is by far the largest chickpea producer in Africa, with a share of nearly $40 \%$ of total production (FAOStat 2014). Geographically, the major chickpea growing areas are North Gonder, East Gojam, West Gojam, South Wollo, and North Showa zones in Amhara and the East, South and South-west Showa zones of Oromia (Van den Broek et al. 2014). According to Agricultural Transformation Agency (2013) and CSA (2013), about 90-95\% of chickpea production takes place in North Gonder, South-west Showa and East Showa. Ethiopia has suitable agro-climatic conditions for the production of Desi and Kabuli types of chickpea. Farmers have traditionally grown Desi type chickpea although recently the Kabuli type has been promoted and is expanding rapidly. The Desi type has red flower and its small-seeded beans are black, golden or brown. Even though the Kabuli type chickpea has been introduced recently, its adoption rate is dramatically increasing in most potential areas mainly due to international markets favor larger-seeded Kabuli varieties. In the export market, Kabuli has markets in the Middle East, Western Europe and North America, whereas Desi type goes to India, Pakistan and Bangladesh.

Most chickpea producing famers sell their produce in grain/dried form following the conventional marketing approach and the process involves different value-chain actors in primary, secondary and tertiary markets. However, in some pocket areas of chickpea producing agro-ecology, farmers try to exploit seasonal opportunities and location advantages by selling their chickpea in green or fresh form (Figure-2). Prominently, GPCP marketing scheme is becoming popular in most neighboring districts of Addis Ababa: including, Akaki, Adaa, Becho, Yerer, and Beke, and similar trend does exist in other cities located in chickpea production agroecology. GPCP is brought to the market in small quantities by farmers and sold for immediate consumption, while dried chickpeas go to domestic and export markets for more complex foods, rather than just being shelled and eaten (Kassa 2014). In later sections, various aspects of green and grain chickpea marketing schemes are thoroughly discussed.

\section{Research Process and Methods}

\subsection{Types of Data and Method of Data Collection}

The study has adopted both formal and informal approaches for generating qualitative and quantitative data related to chickpea production and marketing. This includes Key Informant Interviews with district and kebele-level experts, extension workers, farmers and market actors. ICRISAT's research team also conducted Focus Group Discussions with chickpea selling farmers in Akaki district of Oromia region. The team facilitated field visits, discussions, and consultations with partners and key informants. The engagements and consultations were instrumental in understanding the structure of production and marketing of chickpeas in the study areas. To address the study objectives, green chickpea marketing survey was undertaken during the first week of 2018 . The survey included a sample of value-chain actors at three levels: primary rural markets, secondary markets in Akaki district, and tertiary markets in Addis Ababa. The survey work coincided with chickpea harvesting season and the team had the opportunity to talk to farmers about their marketing decisions. The survey included a total of 72 GPCP selling farmers in 6 kebeles of Akaki district: Gemeda (16.7\%), Hechu (33.3\%), Abu-Gerbi (9.7\%), Gelan-Arabsa (12.5\%), Abu-Lugna (13.9\%) and Dawora-Tino (13.9\%). In addition, information was collected from market actors along the supply chain, ranging from urban wholesalers, brokers (middlemen), and retailers (street vendors), and local processors.

The household-level data was collected by trained enumerators using semi-structured survey instruments under continuous supervision of ICRISAT's research team. Understanding the structure and performance of chickpea marketing system requires data on production volume, transaction costs, market channels and networks, market information, institutional arrangement, and bargaining power of market actors. The survey also included data on farmers' socioeconomic characteristics including gender, age, education, livelihood status, chickpea growing experience, and constraints and opportunities of alternative chickpea marketing schemes. 


\subsection{Methods of Data Analyses}

To analyze the data, the study has adopted both descriptive and econometric methods of data analyses. The descriptive methods (including averages, frequencies, mean difference and chi-square tests) helped us identify and compare the magnitude of key variables of interest along the supply chain. One-way Analysis of Variance (ANOVA) was applied to test whether farmers' income from the sale of GPCP is similar irrespective of their area of operation, proximity to market, livelihood status or trading experience. A multiple linear regression model was employed to determine the main factors that affect the volume of GPCP traded or sold. Thus, the empirical model is specified as:

Volume of GPCP traded = $f$ (farmer's characteristics, market characteristics, chickpea characteristics, institutional support, proximity to market, trading experience, planting period, chickpea type, gender, age, family size, farm size, poverty status, ...)

$\left(Q_{g}\right)_{i}=\beta_{0}+\beta_{1}\left(X_{1}\right)_{i}+\beta_{2}\left(X_{2}\right)_{i}+\beta_{3}\left(X_{3}\right)_{i}+\ldots+\beta_{k}\left(X_{k}\right)_{i}+U_{i}$

Where, $\mathbf{Q}_{\mathbf{g}}$ is the quantity of GPCP traded, $\mathbf{X}$ s are the explanatory or control variables, and U is random error term.

\subsection{Description of the Study Areas}

\subsubsection{Agro-climatic Environment and Production System}

The study has been conducted in Akaki district of Oromia regional states. Geographically, it is located to the southeast of Addis Ababa, the capital of Ethiopia. It has conducive agro-climatic conditions for agricultural activities with immense potential for crop and livestock productions. The minimum, mean, and maximum temperature of the district are $13.7{ }^{\circ} \mathrm{C}, 19.8{ }^{\circ} \mathrm{C}$, and $25.9{ }^{\circ} \mathrm{C}$, respectively. The district has an average elevation of about 2000 meters above sea level. Most farmers practice mixed-farming system: engaged in production of different crops and livestock. The main cereal crops grown in the district are wheat, barley and teff (endemic cereal crop to Ethiopia). Recently, some farmers also produce maize at small scale. The dominant pulse crops planted by most farmers include chickpea, lentil, grass pea/vetch, faba bean, and field pea. About $90 \%$ of the soil is considered as vertisol, which is suitable for chickpea production. Nearly half of the population is urban dweller, so off/nonfarm income sources play pivotal role as means of livelihood. In terms of market access, the district is located along the main road linking Addis Ababa, Debre-Zeit and Adama markets. Compared to chickpea producers in many other parts of the country, producers in Akaki district have improved access to chickpea markets.

\section{Data Analyses and Discussion}

As the descriptive results show, GPCP selling farmers are within the average age range of 36 to 46 years, and significant majority of fresh chickpea selling farmers (97\%) are male. In fact, the process and practice of fresh chickpea marketing excludes the participation of women. To sell fresh chickpea, farmers should travel long distance to reach Akaki or Gerji market points in Addis Ababa and the transaction takes place early morning starting from 4:30 AM with the facilitation of brokers. To maintain its freshness and for ease of transport, retailers or vendors prefer to acquire fresh chickpea during the night (during cool temperature). Furthermore, the loading and unloading of green chickpea is highly labor demanding and may not be convenient for women to actively take part.

There is strong positive relationship between proximity to market and farmers' likelihood of selling chickpea in green form. The main GPCP supplying districts are adjacent to and surround about $70 \%$ of Addis Ababa. For instance, the high percentage of farmers who are selling GPCP are residing in Hechu and Gelan-Arabsa. This has a lot to do with their access and proximity to GPCP market: farmers in Hechu are close to Akaki market and those in Gelan-Arabsa are adjacent to Gerji market. Majority of green chickpea sellers have more than 10 years of chickpea production and marketing experience, but their GPCP marketing experience is not that long. The motive of selling GPCP varies depending on household's livelihood condition: either to meet immediate cash need of desperate households or to target a niche market with profit-oriented production. In terms of area coverage, chickpea is important for farmers: around $40 \%$ area of land has been covered by chickpea in the study households.

With regard to total chickpea production profile of the survey areas, the area of land covered by improved variety (such as Arerti) is significantly higher than the area of land covered by local variety, which is often used for GPCP product. The improved cultivars (1) provide higher yield, (2) withstand the problem of water logging, (3) face rising demand for grain or seed after production, and (4) are less vulnerable to diseases and stress. Overtime, preference for improved variety is getting momentum. In the survey kebeles, the minimum average hectare of land covered by improved variety is 0.5 hectare per producing farmer, whereas it is 0.2 hectare for local variety. In fact, the district is among the potential chickpea producing areas of the country. The average area of land covered by chickpea in sample kebeles of Akaki district is significantly higher than the national average of 0.24 hectare.

As shown in Figure-3, even though farmers are operating almost in the same agroecology, they have significantly different planting period for chickpea. Excluding outliers, farmers' planting period of chickpea often 
extends from early August to late September. In the survey areas, majority of farmers who plan to sell their chickpea in green form plant their chickpea during the period of late July -to- mid August following the strategy of staggering. In GPCP marketing, first movers have special advantage in the market. Since consumers' marginal satisfaction from consuming GPCP declines quickly, so early supply of GPCP is worthwhile for producers and street vendors. Over the past couple of years, chickpea producing farmers have shifted to early planting date as motivated by different factors. According to information collected from farmers, they have shifted their planting date mainly due to three reasons: (1) climate variability i.e., expectation of short/long rainy season (84\%), (2) as a mechanism of copping waterlogging (5\%), and (3) to use the opportunity of selling chickpea in green form (11\%). During the survey work, we have thoroughly explored the motivations of GPCP market actors (e.g., producers, vendors and brokers). For around $61 \%$ of GPCP selling farmers, the main driving force is to meet abject cash need of their households. In the study areas, the period from September to December is a cash deficit period for most households, so the decision of selling GPCP for the niche market comes as a rescue to meet various pressing demands including holidays, school fees etc. The income generated from sale of GPCP is also used for covering the harvesting costs of main crops. Therefore, selling of GPCP is found to be crucial for many resource poor households as it helps them bridge the food gap and eases the burden of transition towards the main crop harvesting (Figure-4). There are also famers who are highly keen and market-oriented to exploit the niche market. This group of farmers patronize GPCP selling with a view to target and take advantage of the niche market and maximize income per hectare. In the survey kebeles of Gemeda, Hechu, Abu-Gerbi, Gelan-Arabsa, Abu-Lugna and DaworTino, the share of income obtained from sale of GPCP (relative to total chickpea income) is about $11.4 \%, 49.9 \%$, $12.1 \%, 40.4 \%, 13.9 \%, 5.3 \%$, respectively. We got compelling evidence that this has a lot to do with their proximity to GPCP market.

\subsection{The Structure and Functioning of GPCP Market}

The supply chain of chickpea grain is quite long and complex. Before reaching the final consumer, it involves a number of actors at primary, secondary and tertiary markets (Shiferaw et al. 2007; Shiferaw and Teklewold 2007). However, the structure and functioning of GPCP market is quite different from that of grain market. Unlike the grain market, it is less complex and involves few number of intermediaries in the supply chain (Figure-5). Furthermore, GPCP has limited shelf life because of perishability and lasts short period of time before it gets dried. For famers and traders, this gives very limited window of opportunity. The three main actors in GPCP marketing are farmers, brokers, and retailors/street vendors. Figure-5 shows the structure of the market coupled with interaction among actors during marketing of GPCP. Farmers have two options to sell GPCP: selling (i) at farmgate or (ii) at GPCP markets points in Addis Ababa. The GPCP market points and main distribution centers in Addis Ababa are Akaki and Gerji. Using the first option, wholesalers, distributors or retailors buy the green chickpea onfarm, and they uproot and transport it to GPCP markets in Addis Ababa. In practice, most sellers use the second option, where famers sell their GPCP by transporting it all the way to Gerji or Akaki market points through the involvement of brokers/middlemen. The brokers facilitate the transaction and receive service fee from selling famers and buying retailors. Table-1 compares and reflects on alternative GPCP marketing options from the perspective of the farmers.

To exploit seasonal production and demand for green chickpea as an opportunity, many street vendors are heavily involved in the selling of GPCP. Prior to chickpea, most of the street vendors/retailors sell different seasonal crops, fruits and vegetables (e.g., fresh maize, oranges, bananas, lettuce and spinach). Vendors mentioned that chickpea trading gives them relatively better profit margin than the sale of other fruits or fresh maize. Covering their costs, such as transportation, they earn upto $300 \operatorname{Birr}^{2}$ ( 11 USD) profit per day (which is almost twice the income they could obtain from the sale of other fruits). More importantly, other fruits such as oranges are available in shops and supermarkets. However, GPCP is not available at such places; the vendors are sole suppliers for consumers and this gives them monopoly power. For the farmer, it is a niche market worthwhile to target and meet the demand.

3.1.1 How does the market of GPCP function: Actors, Processes and Profitability?

For GPCP selling farmers, they have different options to sell their fresh chickpea: including on-farm sell to wholesalers, on-farm sell to retailors, or selling their freshly uprooted chickpea in market points by covering all the transaction costs. The last one is the most common way of marketing GPCP in the study areas. Farmers bring a donkey-load, locally known as 'Chinet' of GPCP to the market points in Gerji or Akaki. To maintain balance on the donkey's back, the chinet is equally divided into two segments called 'Isir'. During the 2017 production season, on average, a chinet of local GPCP was sold at a price of 550 Birr ( 20 USD), whereas a chinet of improved variety GPCP worth around 300 Birr. The price difference is justified by two issues - the local variety is highly preferred for GPCP taste and the lower price of improved variety GPCP might be compensated by its high level of productivity. During the marketing process, GPCP selling farmers should arrive at Gerji or Akaki markets very early in the morning, as early as 4:30 AM. The main reason for coming this early is to insulate the chickpea from day sunlight and to maintain its freshness or turgidity. The transaction is conducted with the mediation and 
facilitation of brokers or middlemen. The brokers receive their service fee from both parties: selling famers and buying retailors/vendors. They charge farmers 100 Birr per chinet (donkey load) of GPCP sold and 40 Birr per chinet from retailors for smoothening transaction and cleaning the area. Although both trading parties (farmers and retailors) feel less comfortable about the presence of brokers, to certain extent brokers institutionalize and lubricate the process of GPCP marketing. For the famers, brokers reduce the burden of facilitation and language barrier. Without brokers' involvement, it is would not be easy for farmers to deal with street vendors, who are very good at bargaining and negotiation.

Often a vendor sells half a chinet (Isir) of GPCP per day. After the purchase of GPCP, the retailors process, clean, and organize it into small bunches (locally called 'Chibits'). A bunch is the smallest unit of GPCP sold to the final consumer for consumption. In 2017 market, a bunch of green chickpea costs 5 Birr to the consumer. Based on our experimentation, a Timad of land (a quarter of a hectare) gives an average of 57 chinets of local variety GPCP, while a chinet yields an average of 212 chibits. A chinet of GPCP when properly dried, gives a grain equivalent of approximately 7 Kilogram plus extra weight attributed to grain feeling $(0.7 \mathrm{Kg})$. This basically means if the crop is allowed to get dried, there is a possibility for few top late comer pods (around 15\%) undergo grain feeling processes that could add upto $10 \%$ more weight. Overall, the net dried weight of a chinet of local GPCP is 7.7 Kg. Therefore, the income generation power of GPCP covering a hectare of land is 241,680 Birr (228 chinet per hectare x 212 chibits per chinet x 5 Birr per chibit). In fact, the recommended plant density per hectare is 333,333 , in which case effectively about $75 \%$ can be marketable.

Based on our market assessment and information received from brokers operating in GPCP markets around Addis Ababa, from early October to end of December, in Gerji and Akaki markets, on average, 100 chinets of GPCP is being traded every day. During this hot selling period, about 9000 chinets of GPCP comes to Addis Ababa markets. The grain equivalent of this is around 69.3 tons of chickpea grain or dividing this by the average productivity of local variety chickpea of 1.6 tons per hectare, it covers about 43.3 hectares of land. In fact, this could go upto 60 hectares if one exhaustively considers farmgate and other fragmented sales in locations not addressed by this survey during the hot selling period.

\subsection{Cost Benefit Analysis (CBA) on Alternative Chickpea Marketing Schemes}

To assess the costs and benefits of alternative chickpea marketing schemes, the production, marketing, and institutional data have been analyzed under two alternative scenarios. As discussed in the introductory section, at national level the average area of land covered by chickpea is approximately a quarter of hectare (locally called a 'Timad' of land). Thus, we try to access the viability of GPCP marketing for a typical smallholder famer who is operating on a Timad of land (Table-2). We have collected yield and market data from framers, district offices and traders. To determine the dry weight equivalent of chickpea sold in green/fresh form, we have carefully dried the green chickpea and carried out weight measuring experiment before and after getting the chickpea dried. According to the yield data obtained from Akaki District Bureau of Agriculture, the average yield of local variety chickpea is 1.6 tons/ha i.e., 0.4 ton per Timad, whereas average yield of improved variety chickpea is around 2.9 tons/ha ( 0.725 ton per Timad). When a famer sells a Timad of local variety chickpea in grain form, he/she gets 8,000 Birr (0.4 ton x 20,000 Birr/ton), but he/she could get 18,125 Birr from the sale of improved variety $(0.725$ ton $\mathrm{x}$ 25,000 Birr/ton). Had it been sold in green or fresh form, the local variety would yield 31,350 Birr (57 Chinet per Timad x 550 Birr per Chinet), while the improved variety would yield upto 15, 000 Birr (50 Chinet per Timad x 300 Birr per Chinet).

Famers would be better-off by selling their local chickpea in green/fresh form (Table-2); the income is almost four times higher than the income from selling it in grain/dried form. On the other hand, the comparative advantage of improved variety chickpea is to sell it grain form. The key message here is that green chickpea marketing is variety-specific and requires the concept of niche market. Whenever farmers chose to sell chickpea in green form, they could save harvest and post-harvest costs: including costs of harvesting, transportations, threshing, guarding and security. Thus, those farmers who decide to sell their chickpea in green form are exempted from such costs. Our findings show that harvest and post-harvest activities account for at least $31 \%$ of the total production cost (Table-3). In fact, this is in line with the findings of Shiferaw et al. (2007). Therefore, the reduction of these costs provides strong support in favor of GPCP marketing. On the other hand, there are benefits forgone or losses to be endured by selling chickpea in green form. One of them is the loss of byproducts of chickpea such as straw and crop residue. After threshing, almost the entire byproduct of chickpea is used as animal feed. It is especially preferred by horses, mules and donkeys. The volume ranges from 1.5 to 4 tons per hectare. According to the information collected from some respondents and previous studies, during dry season farm households that do not have horses or mules sell it to neighbors at an average price of 150 to 250 Birr per ton, accounts for not more than 2 to $5 \%$ of the total income.

By examining how the value chain actors operate in GPCP market, this study hopes to shed some light on the benefit attributed to each of them. As shown in Figure-6, the benefit is asymmetrically distributed among actors. From the sale of a Timad of local variety GPCP, a vendor/retailor earns 60,420 Birr. Therefore, the retailor makes 
around $52 \%$ more revenue, compared to what a producer receives from a Timad of green pod chickpea $(31,350$ Birr). The farmers give around $10 \%$ of their income to brokers for their role of facilitation, while GPCP vendors pay $11 \%$ of their revenue as transport, processing and facilitation costs.

In addition to income difference between GPCP and grain marketing, respondents indicated that GPCP marketing has different benefits for farmers. Importantly, GPCP marketing scheme helps them reduce the problem of immediate cash shortage, involves few intermediaries during the marketing process and is labor saving. When we look at the income effect of selling GPCP, sample farmers in Abu-Lugna and Hechu kebeles earn 36 to $41 \%$ of their annual total income comes from the sale of GPCP. Moreover, the marketing of chickpea in green form has the potential to reduce production and storage related crop risks including post-harvest losses.

3.2.1 Key Considerations and Parameters for GPCP Marketing

During the research process, buyers and consumers of GPCP reveal their preference and give due emphasis to different attributes, qualities and parameters of chickpea. According to the response received from GPCP selling farmers, pod size, pod color, chickpea type (Desi or Kabuli), appearance, price, neatness, and freshness are identified as important attributes (Figure-7). Based on these considerations, black dube from local variety and Mariye from improved variety received the highest ranking. The multivariate regression results also indicated that chickpea characteristics (chickpea type, pod size and color), household characteristics (income level, number of dependents and land size), proximity to market, time of selling GPCP and handling (neatness and freshness) are statistically significant to determine the volume of GPCP traded ${ }^{3}$. Around $46 \%$ of GPCP final consumers are in the age range between 26 to 45 years, followed by those who are in the group of 15 to 25 years (25\%). Most of the buyers in the first group have rural background and they already have a childhood experience of consuming GPCP. The income category and socioeconomic conditions of consumers are quite diverse: ranging from highly welloff/affluent group with car ownership to low income people including students, daily laborers etc. The main target locations for selling GPCP are around bus/taxi stations, parking lots and schools (27\%), and around open markets, shopping center and industry parks (72\%).

3.2.2 The Challenges of GPCP Marketing

According to the responses received from survey farmers and traders, green pod chickpea marketing has different challenges and limitations (Figure-8). One of the limitations is that farmers do not have standard measurement units to sell their fresh chickpea. The weight measurement mechanisms and units (such as chinet and chibit) are arbitrary, inconsistent and unreliable i.e., it requires standardized measurement units. Moreover, GPCP marketing requires early uprooting so that it disrupts the process of nitrogen fixation or aborts its soil maintenance benefits. Unlike grain marketing, farmers have limited possibility for bulk selling, thus they need to load and unload green chickpea for many transactions. This increases fragmentation of efforts in marketing and leads to high transaction costs. The hassle during the process of transaction and the excessive labor requirement makes GPCP marketing less attractive to women producers, so on-farm selling of green chickpea could be a better option for them. Famers also suggested that they receive limited extension support for the production and marketing of GPCP. Variety release and provision of technology options tailored to GPCP production, processing and marketing are very much limited. On the ground, such support system and backstopping efforts are completely missing, although highly needed by farmers. In some study areas, the extension system discourages GPCP marketing with the presumption that the scheme is less profitable for farmers. Furthermore, the size of the market is also an issue for GPCP producers. Related to further scaling of GPCP marketing scheme, around 54\% of GPCP selling farmers responded that the existing market is not adequate for green chickpea trading. With value addition and small investment in processing, packing and labeling, there could be a possibility of reaching more customers through supermarkets and other distribution channels. This will improve the GPCP demand of consumers who are sensitive to health, sanitation, perishability and product origin. This could be a good entry point to formalize and standardize the GPCP marketing scheme.

As indicated in figure-9, the structure and functioning of GPCP marketing system is constrained by different factors. The major constraints and risk factors of GPCP marketing can be categorized under: lack of market information, limited market size and options, price instability, product perishability and low level of institutional support. The GPCP supply originates in small quantities from highly dispersed small producers that supply nonhomogeneous varieties. Therefore, high transaction costs coupled with inadequate access by market participants to timely and accurate information about prices, quality, and demand patterns in various markets are some of the limiting factors (Fafchamps and Hill 2005; Fafchamps and Gabre-Madhin 2006; Shiferaw et al. 2007). Furthermore, the size of GPCP market is not large enough to promote wider adoption of such practice, and it is rather a niche market with unique characteristics. If more farmers resort to GPCP marketing, the size of the market is too small to accommodate substantial number of new entrants. Therefore, care should be taken to aggressively promote and scale-out GPCP marketing in the targeted areas and beyond. Moreover, further efforts on innovative utilization of GPCP products, sanitary improvement and value addition are required to increase the size and diversity of GPCP market. 


\section{Summary, Conclusion and Policy Implications}

Ethiopia is a leading producer of chickpea in Sub-Saharan Africa and the crop plays a huge role in household food and nutrition security, soil fertility restoration and export revenue generation. Recent market studies also show that it is becoming a high-value crop for many smallholder farmers: price and demand for chickpea has increased tremendously during the past five years. Majority of farmers sell chickpea in grain form and the chickpea grain reaches the final consumer through complex channels and long supply chain involving various market actors. However, GPCP marketing of chickpea is a recently evolving phenomenon as niche market. Some chickpea producers, who are operating in the surrounding districts of Addis Ababa, are targeting niche market by supplying GPCP for immediate consumption. Over the past five years, there has been a considerable increase in marketing of GPCP and it has also rising prospects. The structure and functioning of GPCP market is quite different from that of grain market. Unlike the grain market, it is less complex and involves few number of intermediaries within short supply chain, but it has also its own limitations, challenges and rooms for improvement. Despite the relevance of multilayer evidences, the research and development efforts to understand, evaluate and support GPCP marketing scheme are very much limited. To the best of our understanding, this study is the first of its kind to critically examine the viability of GPCP. We hope that the findings of this research could provide policy inputs, help bridge the knowledge gap, and can be used as a reference for further studies in the area.

Our investigation demonstrated that GPCP has not received the attention it deserves. For instance, the release of new crop variety, productivity improvement schemes and extension service provisions of district's Bureau of Agriculture do not take GPCP into account. Farmers are still using very old variety with very minimal extension support. Widening the market base by availing more GPCP product options, processing and value addition efforts (such as cleaning, peeling, cooking, roasting, packaging, and labeling) are almost missing. Some farmers sell GPCP out of necessity, whereas other farmers are highly market-oriented and put effort to exploit the niche market. Their motive of participation is also different: the first group is motivated by cash deficit, but the second group is derived by profit. Besides, GPCP marketing gives temporary employment opportunity for hundreds of urban youth: vendors and brokers.

The policy and research implications of the study are:

- The research and extension system should address the concerns of GPCP producers and engage them during variety release, training provision and capacity building.

- There is limited information and knowledge about the size and characteristics of GPCP market. Evidence generation and further studying the structure and functioning of the market are important entry points to know the viability and scalability of such marketing scheme.

- The findings clearly show that GPCP marketing is variety specific: the market strongly favors the old localized variety. To make GPCP buying decision, market actors such as consumer and vendors consider certain crop parameters and attributes: including, pod color, pod size, freshness, neatness, pods per plant, variety (Desi or Kabuli) etc. Advisory services for new entrants should take these issues into account.

- While targeting a niche and aiming for further scaling or expansion, there should be enough evidence to make sure that there are enough buyers in the niche: this could make it viable and sustainable.

- At higher level, mainstreaming GPCP into food and nutrition product stream could have paramount importance.

- As way of generating evidences, we strongly recommend further research considerations related to GPCP marketing.

\section{Reference}

Agricultural Transformation Agency (2013), 'Working Strategy for Strengthening Ethiopia's Chickpea Value chain: Vision, Systemic Challenges and Prioritized Interventions'.

Asfaw, Solomon, Shiferaw, Bekele, and Simtowe, Franklin (2010a), 'Does technology adoption promote commercialization? Evidence from chickpea technologies in Ethiopia', CSAE 2010 conference on Economic Development in Africa, University of Oxford, UK, 21-23.

Asfaw, Solomon, et al. (2012), 'Impact of modern agricultural technologies on smallholder welfare: Evidence from Tanzania and Ethiopia', Food policy, 37 (3), 283-95.

Asfaw, Solomon, et al. (2010b), 'Socio-economic Assessment of Legume Production, Farmer Technology Choice, Market Linkages, Institutions and Poverty in Rural Ethiopia: Institutions, Markets, Policy and Impacts Research Report No. 3', Field Crops Research, 36 (2), 103-11.

Atnaf, Mulugeta, Tesfaye, Kassahun, and Kifle, D (2015), 'The Importance of legumes in the Ethiopian farming system and overall economy: An overview', Am J Exp Agric, 7 (6), 347-58.

Aw-Hassan, Aden, Yirga, Chilot, and A Yigezu, Yigezu (2015), 'Tracking Adoption and Diffusion of Improved Chickpea Varieties: Comparison of Approaches'.

Chichaybelu, Mekasha, et al. (2017), 'Advances in chickpea crop improvement for improved productivity and resilient cropping systems in Ethiopia'. 
Chilot, Y, et al. (2010), 'Pulses value chain potential in Ethiopia: Constraints and opportunities for enhancing exports', International Food Policy Research Institute, Pulses Diagnostics, 1-3.

CSA, Central Statistical Agency (2013), 'Agricultural Sample Survey 2012/2013: Report on Area and Production of Major Crops in 2013', I.

Dadi, Legesse, et al. (2005), 'Adoption studies on improved chickpea varieties in Ethiopia'.

Demissie, Mitiku (2011), 'Marketing of Kabuli and Desi Chickpeas by Smallholder Farmers in Eastern Shewa Zone', (Haramay University).

Fafchamps, Marcel and Hill, Ruth Vargas (2005), 'Selling at the farmgate or traveling to market', American journal of agricultural economics, 87 (3), 717-34.

Fafchamps, Marcel and Gabre-Madhin, Eleni (2006), 'Agricultural markets in Benin and Malawi'.

FAOStat (2014), FAO Country Profile: Legumes Prodution and Productivity.

Fikre, Asnake (2014), 'An overview of chickpea Improvement Research Program in Ethiopia', The journal of the International Legume Society (3).

Genene, Sara (2013), 'Shimbra Eshet: Addis Ababa Relishing Fresh Green Chickpeas', Ethiopian Wanderlust.

Gowda, CLL, et al. (2014), 'Unlocking Opportunities in African Pulses Production through Public-Private Partnerships'.

Hellin, Jon and Higman, Sophie (2002), Smallholders and niche markets: Lessons from the Andes (Overseas Development Institute).

IFPRI (2010), 'Pulses value-chain in Ethiopia: Constraints and opportunities for enhancing exports. Working Paper.'.

Kassa, Lucy (2014), 'The Seasonal Chickpea Crop', Addis Fortune.

Rao, NVPRG, et al. (2012), 'Enhancing Chickpea Productivity and Production in Eastern and Southern Africa'.

Rashid, Shahidur, et al. (2010), 'Pulses Value Chain in Ethiopia. Constraints and Opportunities for enhancing Exports', International Food Policy Research Institute. Washington, DC, USA, 1 (10).

Shiferaw, Bekele and Teklewold, Hailemariam (2007), 'Structure and functioning of chickpea markets in Ethiopia: Evidence based on analyses of value chains linking smallholders and markets'.

Shiferaw, Bekele, et al. (2007), 'Analysis of production costs, market opportunities and competitiveness of Desi and Kabuli chickpeas in Ethiopia'.

Tefera, Tewodros (2014), 'Analysis of Chickpea Value Chain and Determinants of Market Options Choice in Selected Districts of Southern Ethiopia', Journal of Agricultural Science, 6.

Thilmany, Dawn (2012), 'What are niche markets? What advantages do they offer?', Assessment and Strategy Development for Agriculture.

Van den Broek, Joep, et al. (2014), 'Legume Value-Chains in Ethiopia-Landscaping Study', 77.

Verkaart, Simone, et al. (2017), 'Welfare impacts of improved chickpea adoption: A pathway for rural development in Ethiopia?', Food policy, 66, 50-61.

Verkaart, Simone, et al. (2018), 'A recipe for success? Learning from the rapid adoption of improved chickpea varieties in Ethiopia', International Journal of Agricultural Sustainability, 1-15.

Yadav, SS, et al. (2007), 'Uses, consumption and utilization', Chickpea Breeding and Management, 101-42.

Zegeye, Fisseha, et al. (2016), 'Gender in chickpea research and development of Ethiopia: achievements, challenges and future direction', Harnessing Chickpea Value Chain for Nutrition Security and Commercialization of Smallholder Agriculture in Africa, 256.

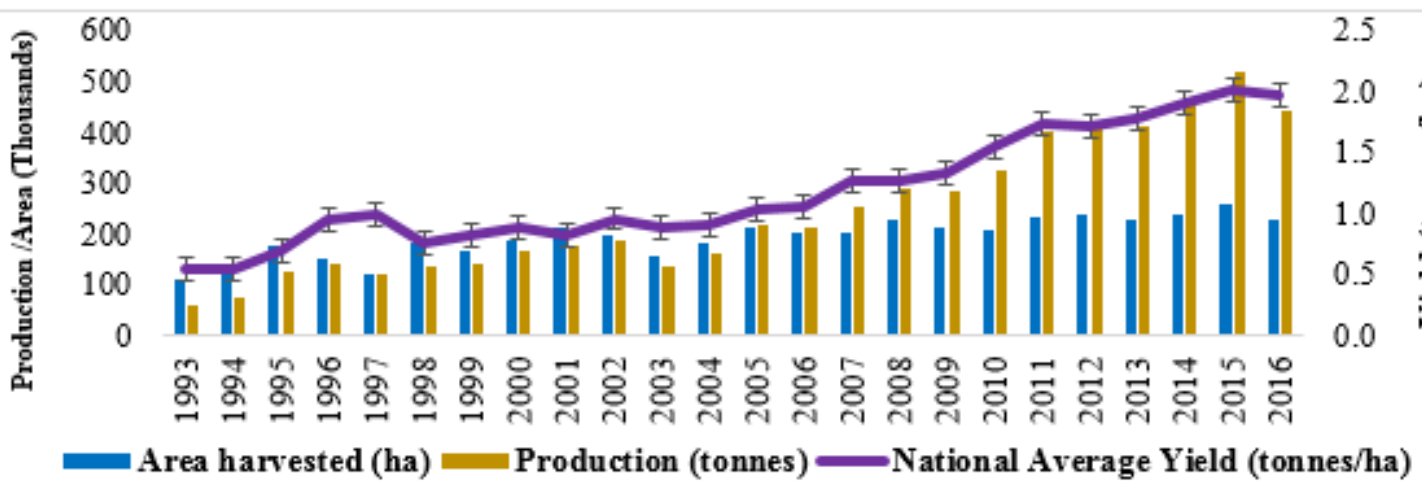

Figure-1: Production and Productivity of Chickpea in Ethiopia (1993-2016) Source: FAOStat (2017) 


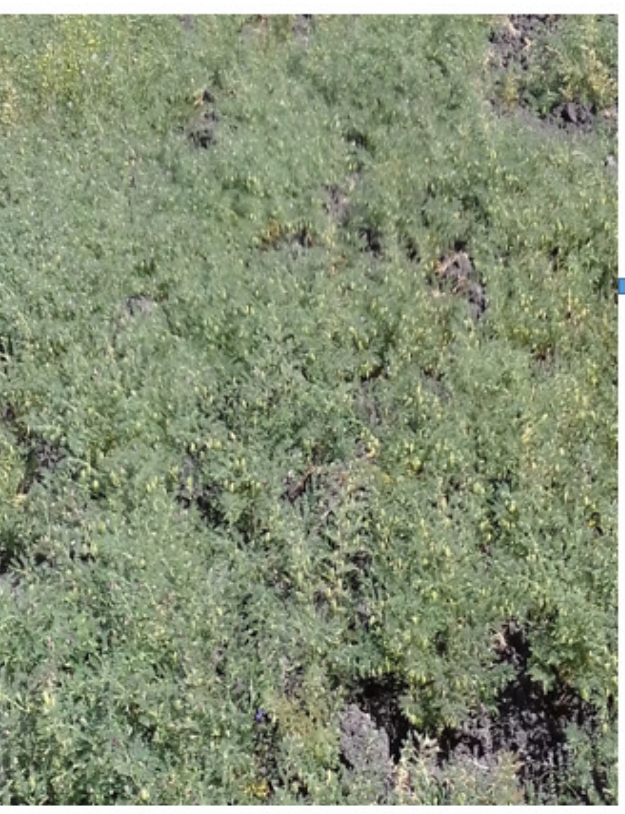

GPCP Chickpea Field

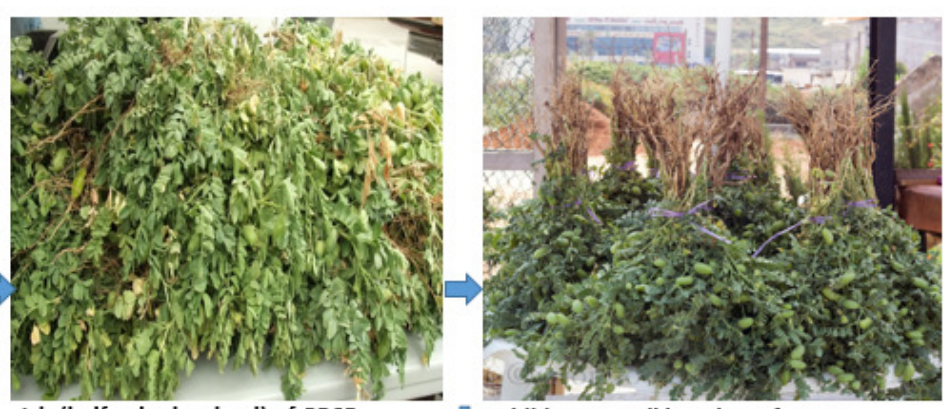

Isir (half a donkey load) of GPCP

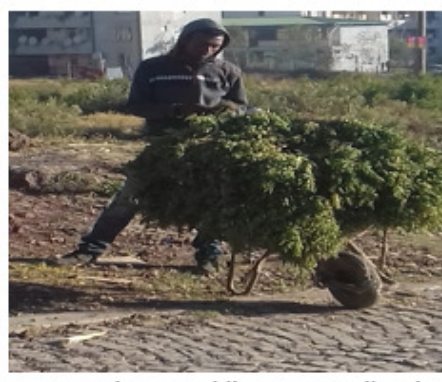

A young boy a mobile GPCP vending duty

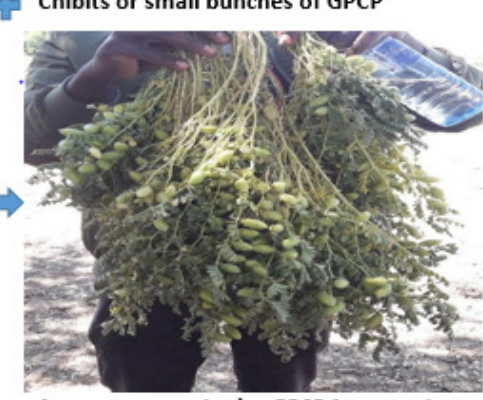

A consumer purchasing GPCP from vendor

Figure-2: The Process and Actors in GPCP Marketing Scheme

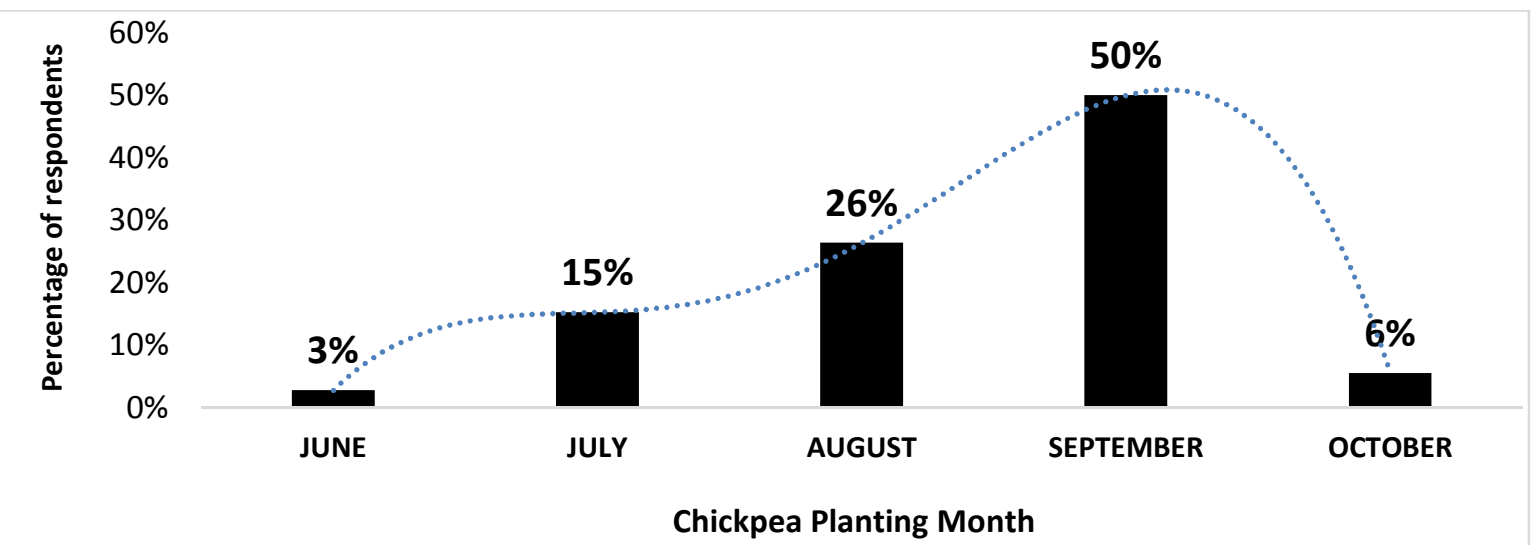

Figure-3: Chickpea Planting Period for Sample Respondents

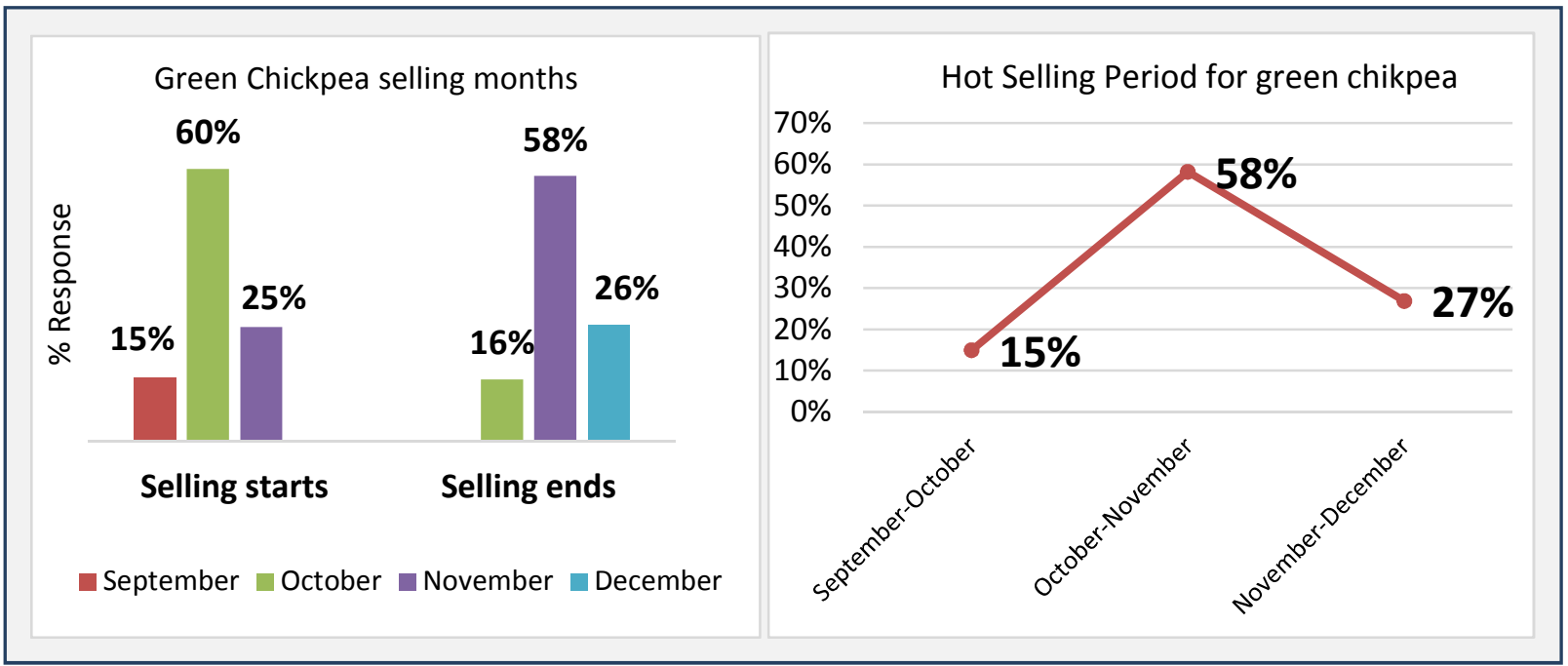

Figure-4: Hot selling period of green chickpea 


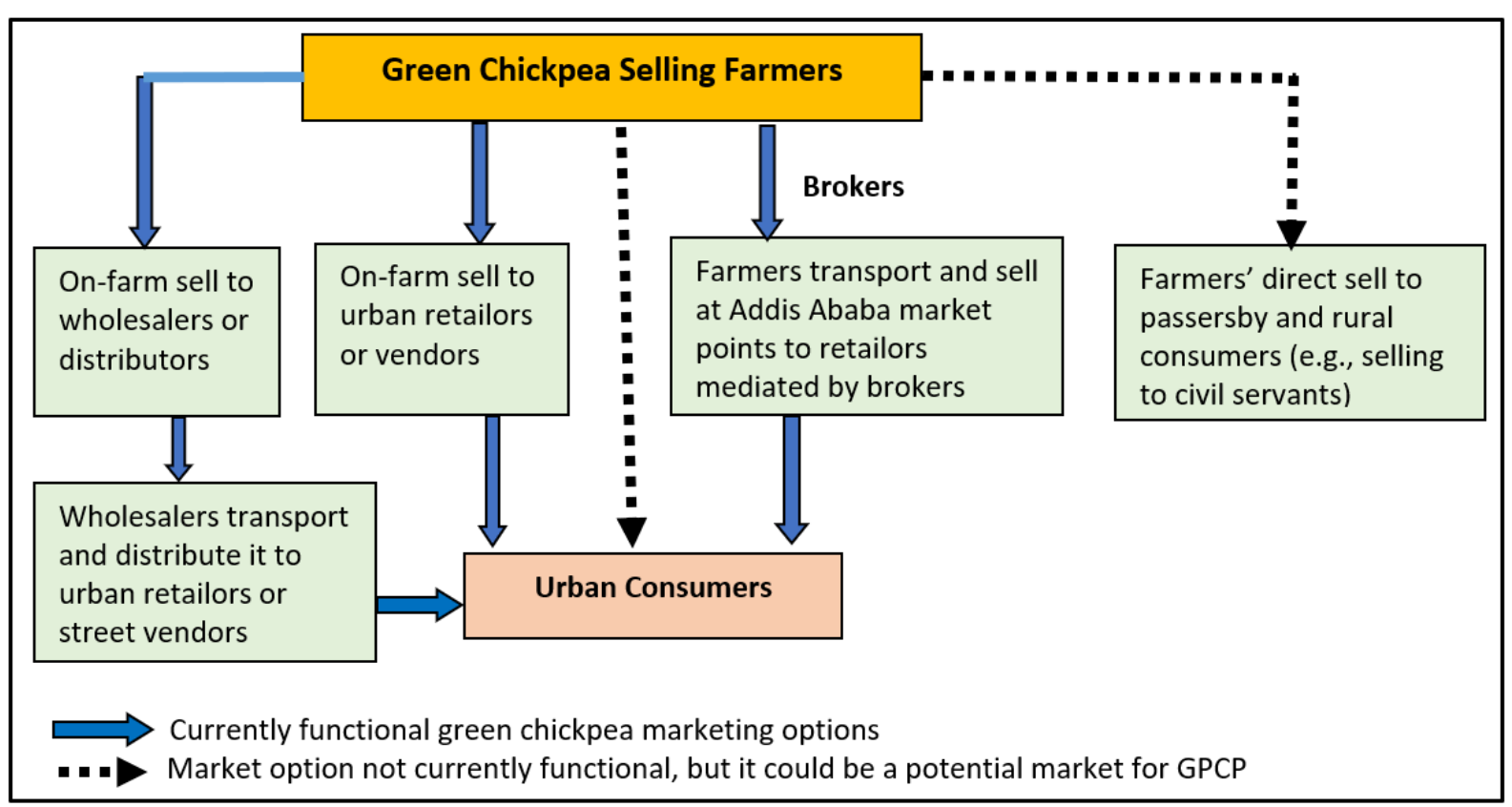

Figure-5: The Structure of GPCP Market

Table-1: Evaluation and characterization of alternative GPCP marketing options

\begin{tabular}{|c|c|c|c|c|c|}
\hline GPCP Market Options & $\begin{array}{l}\text { Price } \\
\text { received } \\
\text { by the } \\
\text { farmer }\end{array}$ & $\begin{array}{l}\text { Transaction } \\
\text { cost per } \\
\text { quantity traded }\end{array}$ & $\begin{array}{l}\text { Market } \\
\text { Risk for } \\
\text { farmers }\end{array}$ & $\begin{array}{l}\text { Frequency } \\
\text { of } \\
\text { Transaction }\end{array}$ & $\begin{array}{l}\text { Farmers' } \\
\text { bargaining } \\
\text { power }\end{array}$ \\
\hline $\begin{array}{l}\text { 1. On-farm sell to large-scale } \\
\text { buyers, distributors or } \\
\text { brokers }\end{array}$ & Moderate & Very low & Very low & Low & Very High \\
\hline 2. On-farm sell to Retailers & Low & Moderate & Low & High & Moderate \\
\hline 3. On-farm sell to consumers & Moderate & High & Moderate & High & Moderate \\
\hline $\begin{array}{l}\text { 4. Selling at Akaki or Gerji } \\
\text { GPCP market points }\end{array}$ & High & High & High & Moderate & Very Low \\
\hline
\end{tabular}

Table-2: The Benefits of Alternative Chickpea Marketing Scenarios or Options

\begin{tabular}{|l|c|c|c|}
\hline Marketing & \multicolumn{1}{|c|}{ Description } & \multicolumn{2}{c|}{ Benefits in Birr per Timad (in Birr) } \\
\cline { 3 - 4 } Scenarios & \multicolumn{1}{|c|}{ Local variety } & Improved variety \\
\hline Scenario I & $\begin{array}{l}\text { When chickpea covering a Timad of land } \\
(0.25 \text { hectare) was sold in green/fresh form }\end{array}$ & 31,350 & 15,000 \\
\hline Scenario II & $\begin{array}{l}\text { When the farmer sells a Timad of chickpea } \\
\text { in Grain/Dried form }\end{array}$ & 8,000 & 18,125 \\
\hline
\end{tabular}


Table-3: The Share and Composition of Harvest and Post-harvest costs

\begin{tabular}{|l|l|l|}
\hline $\begin{array}{l}\text { Harvest or Post-harvest } \\
\text { Activities }\end{array}$ & \multicolumn{1}{|c|}{$\begin{array}{c}\text { Cost per } \\
\text { Timad (in } \\
\text { Birr) }\end{array}$} & Comments and/or Justifications \\
\hline Harvesting & $6 \times 100=600$ & $\begin{array}{l}\text { Harvesting a timad (0.25 ha) of chickpea requires six } \\
\text { persons per day. The price per person is 100 Birr. }\end{array}$ \\
\hline $\begin{array}{l}\text { Transporting harvest to threshing } \\
\text { point }\end{array}$ & $4 \times 120=480$ & $\begin{array}{l}\text { We require two people with 4 donkeys. The rental rate } \\
\text { for a donkey is 120 Birr per day. }\end{array}$ \\
\hline $\begin{array}{l}\text { Threshing and Transporting } \\
\text { produce }\end{array}$ & $\begin{array}{l}3 \times 150=450 \\
\text { Total }=690\end{array}$ & $\begin{array}{l}\text { Assuming there is wind, 3 pairs of oxen are required } \\
\text { for threshing. A pair of oxen costs 150 Birr per day. } \\
\text { For transporting produce, two donkeys cost 240 } \\
\text { Birr/day. Often family labor is used to facilitate these } \\
\text { activities. }\end{array}$ \\
\hline $\begin{array}{l}\text { Processing Cost (e.g. winnowing, } \\
\text { purifying, packaging) }\end{array}$ & Not applicable & $\begin{array}{l}\text { In the study areas, family labor is often used for these } \\
\text { activities }\end{array}$ \\
\hline Pesticides during storage & 48 & $\begin{array}{l}\text { Price per celphos is 3 Birr, where one celphose is } \\
\text { enough for 0.1 ton }\end{array}$ \\
\hline Total Harvest \& post-harvest costs & 1818 & $\begin{array}{l}\text { Assuming that farmers used improved varieties, land } \\
\text { is not rented, and there is wind during threshing. The } \\
\text { use of family labor is assumed. }\end{array}$ \\
\hline Total production costs & $\mathbf{5 8 3 6}$ & \multicolumn{2}{|c|}{} \\
\hline
\end{tabular}

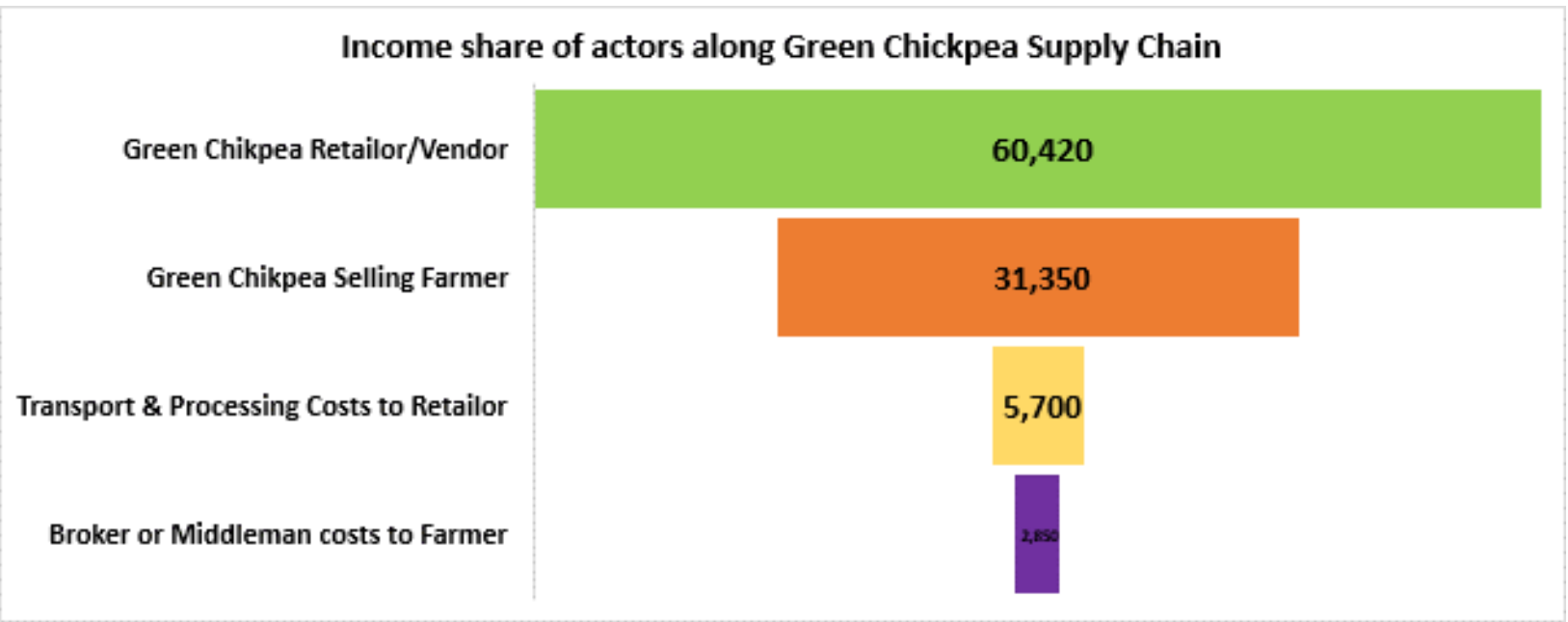

Figure-6: Value-Chain Actors and their share of Income per Timad of GPCP

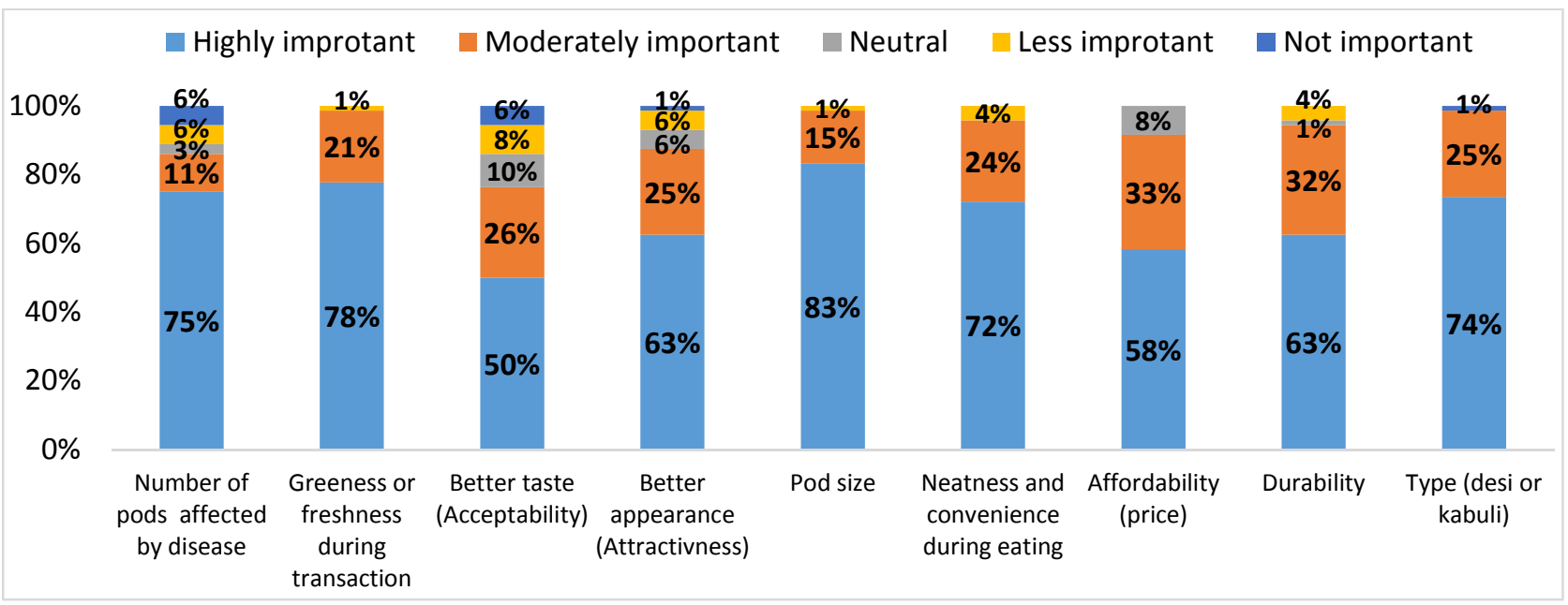

Figure-7: Important attributes of chickpea for green marketing 


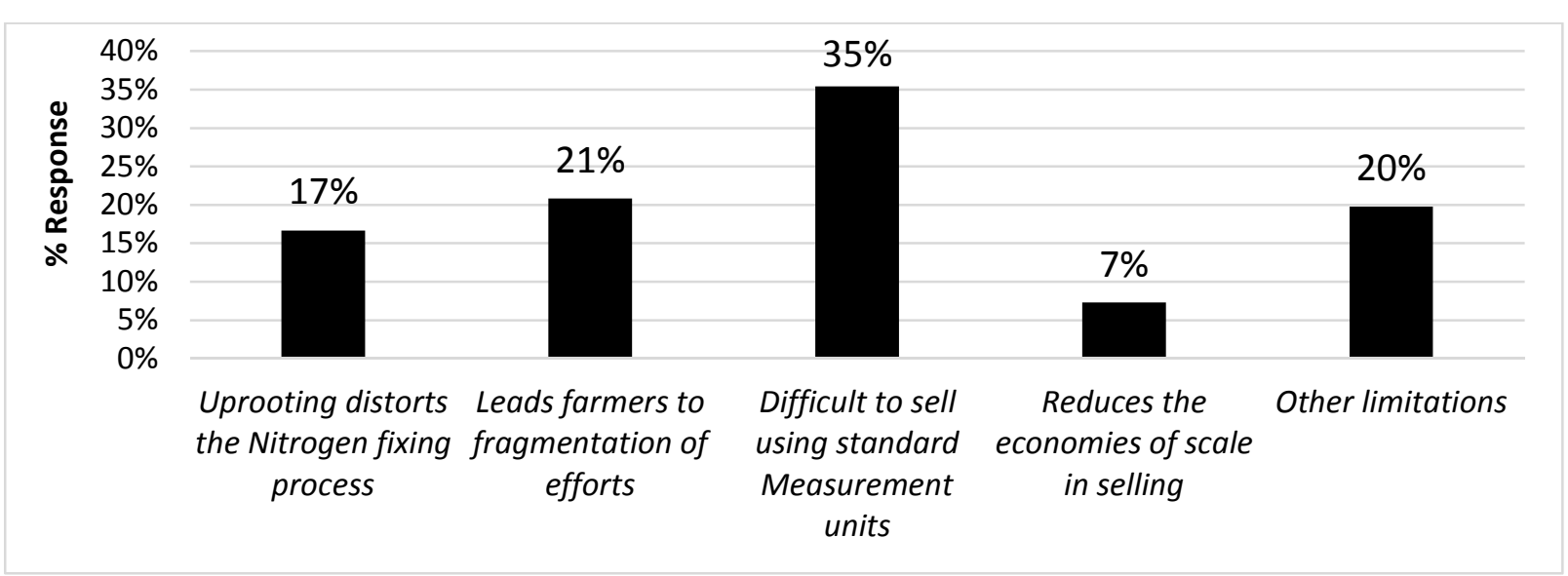

Figure-8: Limitations of selling Chickpea in Fresh or Green form

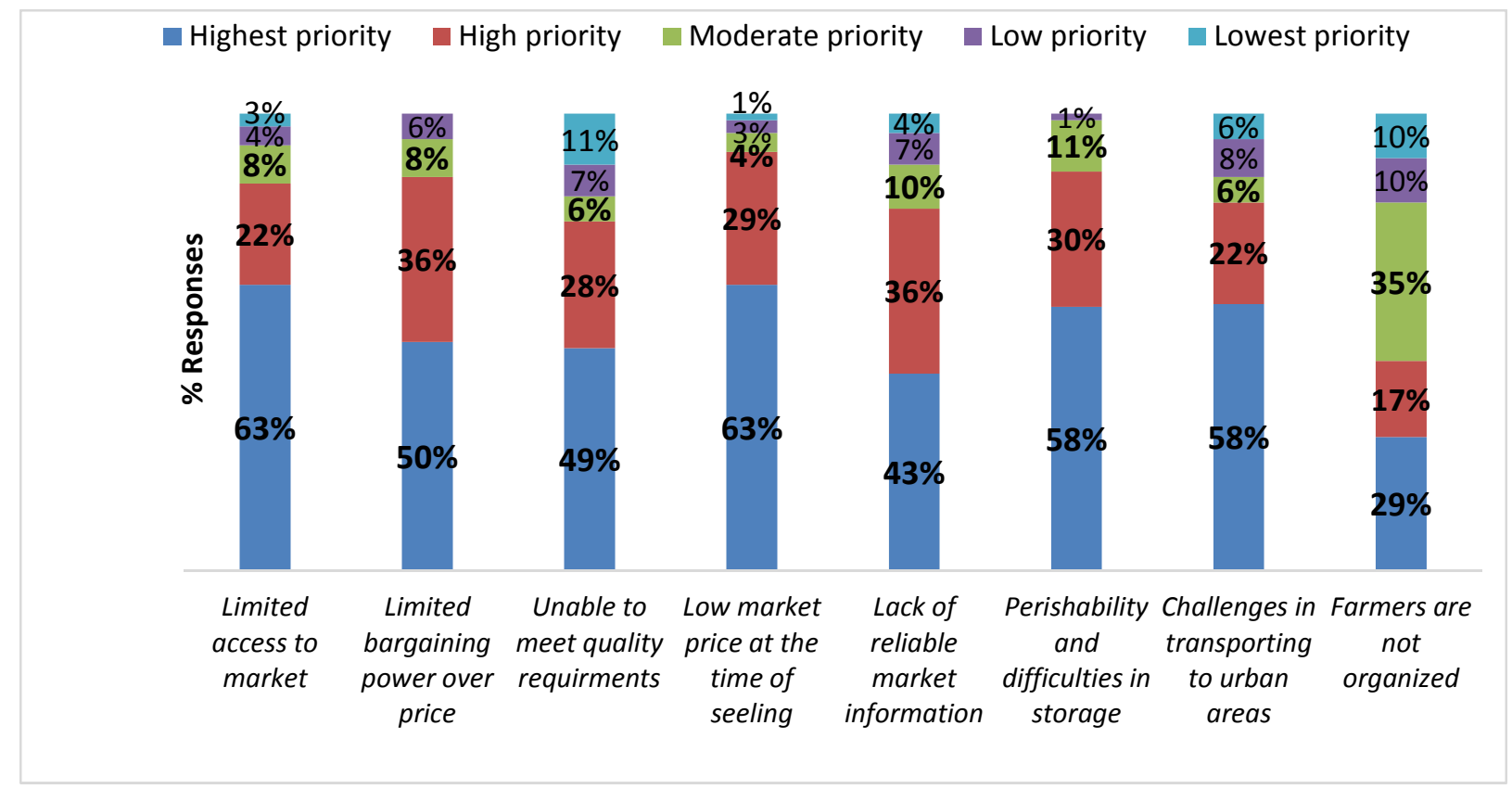

Figure-9: Major Underlying Constraints of marketing GPCP

Notes

\footnotetext{
${ }^{1}$ In the current context of Ethiopia, Kebele is the lowest administrative unit, similar to a ward or a neighborhood. A kebele is composed of villages or Peasant Associations (PAs). Besides, kebeles form a District (Woreda).

${ }^{2}$ The Birr is the unit of currency in Ethiopia. Currently, one USD is equivalent to 28 Ethiopian Birr.

${ }^{3}$ Due to space consideration, the regression results have not been reported. It can be accessed upon a request from the authors.
} 